\title{
Alzheimer's disease and cytokine IL-10 gene polymorphisms: is there an association?
}

\author{
A doença de Alzheimer e os polimorfismos no gene da citocina IL-10: há alguma associação? \\ Carolina Antunes Magalhães', Maria das Graças Carvalho', Lirlândia Pires de Sousa', Paulo Caramelli², \\ Karina Braga Gomes ${ }^{1}$
}

\begin{abstract}
Alzheimer's disease (AD) is the most common form of dementia. In the last 15 years, a new theory has proposed the autoimmune mechanism as a trigger for AD. Studies on the association between AD and inflammatory biomarkers have yielded controversial results. Interleukin-10 (IL-10), an anti-inflammatory mediator, has been pointed out as one of the main cytokines associated with the occurrence of AD. Moreover, treatment that increases IL-10 levels could be a potential therapy for AD, since this cytokine acts on amyloid and pro-inflammatory molecule reduction. Based on the current literature, this study reviews evidence regarding the role of $I L-10$ polymorphisms in the context of $A D$, which has been shown to be of paramount importance for attenuating neuroinflammation, cognitive dysfunction and neurodegeneration.
\end{abstract}

Keywords: Alzheimer's disease; inflammation; Interleukin-10.

\section{RESUMO}

A doença de Alzheimer (DA) é a forma mais comum de demência. Nos últimos 15 anos, uma nova teoria propõe um mecanismo autoimmune como o gatilho para a DA. Associações entre DA e biomarcadores inflamatórios têm sido registradas, contudo com resultados controversos. A interleucina-10 (IL-10), um mediador anti-inflamatório, tem sido apontada como uma das principais citocinas associadas com a ocorrência de DA. Além disso, os tratamentos que aumentam os níveis de IL-10 podem ser uma terapia potencial para DA, uma vez que esta citocina atua sobre a redução de substância amiloide e de moléculas pró-inflamatórias. Baseando-se em literaturas atuais, este estudo revisa evidências relacionadas com o papel da IL-10 e seus polimorfismos no contexto da DA, o qual se mostrou ser de fundamental importância para atenuar a neuroinflamação, a disfunção cognitiva e a neurodegeneração.

Palavras-chave: doença de Alzheimer; inflamação; interleucina-10.

Alzheimer's disease (AD), the most common form of dementia, is a global public health problem challenging the older generation ${ }^{1}$. Alzheimer's disease is a neurodegenerative disorder characterized by injury to brain regions responsible for controlling memory and other cognitive functions. In this way, this disease compromises the ability to learn, reason, communicate, and carry out daily activities, and is accompanied by personality and behavioral changes 2 .

According to the Alzheimer's Association, in the United States, one person develops AD every 67 seconds. By 2050, one case every 33 seconds is predicted, resulting in one million new cases per year ${ }^{1}$. Nitrini et al. found a prevalence for dementia in seven percent of the elderly, aged 65 or older, in Latin America ${ }^{3}$.

Neuropathology in $\mathrm{AD}$ is characterized by altered formation of amyloid- $\beta$ (A $\beta$ ) plaques and hyperphosphorylation of the tau protein associated with neurofibrillary tangles ${ }^{4,5}$. According to Rosenberg et al. ${ }^{6}$, genotype-phenotype correlations of $\mathrm{AD}$ provide a comprehensive appreciation of the spectrum of disease causation. The inflammatory process is another main pathophysiological factor associated with $\mathrm{AD}^{7,8}$.

In the last 15 years, a new theory has proposed the autoimmune mechanism as a trigger for $\mathrm{AD}$. This theory involves a dysregulation of the blood-brain barrier, neurons, microglia, astrocytes and multiple cytokines ${ }^{9,10,11}$. As reviewed by Naert and Rivest, activated microglia and astrocytes secrete inflammatory cytokines and chemokines, while age-related inflammation and chronic infection with herpes viruses might contribute to the systemic inflammation ${ }^{12}$.

Microglia activation is supposed initially to be a result of tissue injury and amyloid plaque deposition due to a cytotoxic

1 Universidade Federal de Minas Gerais, Faculdade de Farmácia, Departamento de Análises Clínicas e Toxicológicas, Belo Horizonte MG, Brasil; ${ }^{2}$ Universidade Federal de Minas Gerais, Faculdade de Medicina, Departamento de Clínica Médica, Belo Horizonte MG, Brasil.

Correspondence: Karina Braga Gomes; Faculdade de Farmácia da UFMG; Avenida Antônio Carlos, 6627; 31270-901 Belo Horizonte MG, Brasil; E-mail: karinabgb@gmail.com

Support: Fundação de Amparo à Pesquisa de Minas Gerais (FAPEMIG), Conselho Nacional de Desenvolvimento Científico e Tecnológico (CNPq) and Coordenação de Aperfeiçoamento de Pessoal de Nivel Superior (CAPES). LPS, MGC, PC and KBG are grateful to CNPq Research Fellowship (PQ).

Conflict of interest: There is no conflict of interest to declare.

Received 09 February 2017; Received in final form 04 June 2017; Accepted 13 June 2017. 
response in the brain ${ }^{13,14}$. Activated microglia and astrocyte clusters at sites of neuritic plaques release a variety of inflammatory mediators ${ }^{15}$, including pro- and anti-inflammatory cytokines that play critical roles in the development and progression of $\mathrm{AD}^{16,17,18,19}$.

The associations between $\mathrm{AD}$ and inflammatory biomarkers, including the interleukins IL-1 $\beta$, IL-2, IL-4, IL-6, IL-8, IL-12, IL-18, interferon (IFN)- $\gamma$, tumor necrosis factor (TNF)- $\alpha$, transforming growth factor (TGF)- $\beta$, and the C-reactive protein have been registered with controversial results ${ }^{20}$. However, interleukin-10 (IL-10), an anti-inflammatory mediator, has been pointed out as one of the main cytokines associated with the occurrence of $\mathrm{AD}^{5,9,10}$. Therefore, this study reviewed evidence of the role of $\mathrm{IL}-10$ and its genetic polymorphisms in the context of $\mathrm{AD}$. Our hypothesis is that decreased levels of IL-10, an anti-inflammatory cytokine, and its polymorphisms contribute to an increase in the inflammatory process, which should favour the development of $\mathrm{AD}$, reinforcing the link between inflammation and cognitive decline in elderly people.

\section{METHODS}

Our search was conducted in Pubmed, the Cochrane Library, Science Direct, Scopus and Web of Science databases with the terms "Alzheimer's disease", "inflammation", "interleukin-10", and studies reporting on "associations between Alzheimer's disease and interleukin-10”, with no date restrictions. In this search, 60 works published between 1989 and 2016, in the English language, were identified and included in the present review.

\section{IL-10 and immunomodulation}

Cytokines are small proteins secreted by activated cells. They can affect other target cells or even the same cell that secreted these cytokines. Cytokines are responsible for the communication between cells and play an important role in the physiological and pathological inflammation processes $^{21}$. Interleukins, one of the main types of cytokines, are small glycoproteins, secreted by activated leukocytes. Interleukins are involved in macrophages and $\mathrm{T}$ lymphocyte activation, proliferation and toxicity. Defects of interleukin production may be associated with several disorders. There are more than 36 types of interleukins chronologically numbered in the order of their discovery, one of them being IL- $10^{22}$.

Interleukin-10 is a $36-\mathrm{KDa}$ homodimeric cytokine described by Fiorentino et al. as a "cytokine synthesis inhibitory factor", because of its ability to suppress cytokine production from all $\mathrm{T}$ cell types ${ }^{23}$. The main IL-10 sources in vivo are monocytes, macrophages, dendritic, B, NK and mast cells, T-cells, as well as neutrophils and eosinophils.
In monocytic cells, IL-10 influences antigen presentation, release of immune mediators and phagocytosis ${ }^{21}$.

Interleukin-10 opposes the actions of the pro-inflammatory cytokines and appears to be a suppressor of both immunoproliferative and inflammatory responses in the brain, reducing synthesis of pro-inflammatory cytokines, suppressing cytokine receptor expression, and inhibiting receptor activation ${ }^{21,24}$. Expression of the pro-inflammatory cytokines with a central role in inflammation and cell death, such as IL-1, IL-2, IL-6, IL-8, IL-12, TNF- $\alpha$, and IFN- $\gamma$, are negatively controlled by the immunomodulatory action of IL-10 23 .

\section{Alzheimer's disease and IL-10 effects}

It is known that a chronic inflammatory process accompanies $\mathrm{AD}$. However, it remains unclear whether inflammation is a reaction to the pathology of $\mathrm{AD}$ or a contribution to the onset, or progression, of the disease ${ }^{25}$. The observation of the reactive astrocytes and activated microglia cells, associated with senile plaques in $\mathrm{AD}$, reinforces the inflammatory mechanisms in the pathogenesis of this disease. This mechanism is also supported by the observation of a decreased incidence of $\mathrm{AD}$ in patients who receive long-term nonsteroidal anti-inflammatory drugs ${ }^{26}$.

According to Combarros et $a .^{25}$, certain combinations of genetic variants in the regulatory regions of the two genes, i.e. IL-6-174G/C (rs1800795) and $I L-10-1082 \mathrm{~A} / \mathrm{G}$ (rs1800896) contribute to chronic inflammation in elderly people, increasing the risk of $\mathrm{AD}$. An imbalance between pro-inflammatory and anti-inflammatory cytokines may, therefore, be an important phenomenon in $\mathrm{AD}$. This hypothesis is supported by studies, which described an increase of seven- to ten-fold in the production of IL-1 $\beta$ over IL-10 levels in $\mathrm{AD}$ patients when compared with control subjects ${ }^{26}$. Indeed, Rota et al. did not detect abnormal levels of IL-10 in either cerebrospinal fluid or serum of $\mathrm{AD}$ patients ${ }^{27}$.

Richwine et al. observed that a peripheral injection with lipopolysaccharide, in IL-10-deficient mice, causes a prominent cognitive deficit when compared with wild-type mice ${ }^{28}$. Kiyota et al. ${ }^{10}$ demonstrated that IL-10 significantly reduced neuroinflammation, enhanced neurogenesis and improved spatial cognitive dysfunction in transgenic $\mathrm{AD}$ mouse models. They showed that treatment with IL-10-adeno-associated virus of double-transgenic mice expressing familial $\mathrm{AD}$ mutants of amyloid precursor protein+presenilin-1 (APP+PS1 Tg), could suppress astro/microgliosis. According to the authors, these findings support the concept that IL-10 may ameliorate neuroinflammation, cognitive dysfunction and neurodegeneration.

Corroborating these findings, Henderson ${ }^{29}$ suggested that post-menopausal administration of estrogens may delay the onset, or contribute to the prevention of $\mathrm{AD}^{29}$ by increasing the secretion of IL-10 from microglial cells ${ }^{30,31}$. Moreover, resveratrol, a natural polyphenol reported to have anti-inflammatory 
effects, is able to up-regulate both $I L$ - 10 gene expression and IL-10 levels, which could explain its neuroprotective properties $^{32}$. Bagyinszky et al. ${ }^{22}$ disclosed that IL-10 treatment could be a potential therapy for $\mathrm{AD}$ since this cytokine could act on amyloid reduction by inducing the production of anti-inflammatory molecules, and inhibition of pro-inflammatory cytokines, probably by down-regulating their expression.

However, Guillot-Sestier et al. ${ }^{33}$ found that crossing the (APP+PS1 Tg) mouse model of cerebral amyloidosis with animals deficient in IL-10 demonstrated that genetic blockade of IL-10 mitigates cerebral amyloidosis in APP/PS1 mice. In line with these results, Chakrabarty et al. reported that enhanced IL-10 expression in brains of APP transgenic mice leads to increased $A \beta$ accumulation and worsening of behavioral deficits $^{34}$. These results suggest that rebalancing cerebral innate immunity and promoting beneficial neuroinflammation may be more efficacious than generalized anti-inflammatory therapy for $\mathrm{AD}$. Indeed, according to Bryson and $\mathrm{Lynch}^{35}$, antiinflammatory therapy has not been proven to be of value in the treatment of $\mathrm{AD}$ and inflammatory changes, once a certain stage of inflammation is reached.

Zheng et al. ${ }^{36}$ reviewed studies in order to understand the importance of the role of cytokines or neuroinflammation in $\mathrm{AD}$ etiology and pathogenesis, suggesting the imbalance of pro- and anti-inflammatory activity in $\mathrm{AD}$. According to them, inconsistent outcomes involve IL-10: this cytokine drives macrophage polarization - M1 to M2, which is associated with deactivation of microglia; overexpressing tau increases secretion of IL-10 in rat microglia, which show greater phagocytosis of microspheres; knockout mice show the benefit of IL-10 removal ${ }^{32}$. However, some meta-analysis studies have not found significant differences in IL-10 levels between subjects with mild cognitive impairment (MCI) and healthy controls. Moreover, IL-10 overexpressing in AD animal models weakened the phagocytosis of soluble A $\beta$ by microglia and exacerbated $\mathrm{A} \beta$ deposits in cognitive impairment. They highlighted that the association of IL-10 with $\mathrm{AD}$ requires further study based on genetic polymorphisms as well as the changing levels of this cytokine in $\mathrm{AD}$ patients ${ }^{36}$.

\section{Alzheimer disease and IL10 gene polymorphisms}

The pro- and anti-inflammatory cytokine genes have been studied as potential candidates for the individual's susceptibility to $\mathrm{AD}$; however, no preferential role has been clearly identified ${ }^{37}$, even with opposing results $^{38}$ (Table).

Interleukin -10 is encoded by a gene located on the long arm of chromosome 1 between positions 31 and $32^{39}$. The regulatory regions of the $I L-10$ gene have been associated with chronic inflammatory diseases, such as systemic lupus erythematosus, rheumatoid arthritis, Sjogren's syndrome, as well as the development of dementia ${ }^{9,40}$. Some polymorphisms have been associated with $I L$ - 10 gene expression (Figure).
Several single nucleotide polymorphisms (SNPs) in the regulatory region of $I L$ - 10 were reported to be associated with modulation of IL-10 production. This may result in an imbalance of the regulatory effect of IL-10 on pro-inflammatory cytokines with a subsequent imbalance of the immune response ${ }^{41,42}$. Lio et al. ${ }^{41}$ evaluated the role of $I L-10$ polymorphisms and $\mathrm{AD}$ development in a group of patients from northern Italy. In $132 \mathrm{AD}$ patients and 213 healthy controls, they investigated the prevalence of SNPs -1082A/G, -819C/T (rs1800871) and -592C/A (rs1800872) in the $I L-10$ promoter region. The frequency of $-1082 \mathrm{~A}$ carriers, which are associated with a low production of IL-10, was significantly increased among $\mathrm{AD}$ patients. Thus, these authors concluded that the presence of the -1082A allele, associated with a low production of IL-10, may be considered as an additive and independent genetic risk factor for $\mathrm{AD}^{41}$. In the same year, Depboylu et al. ${ }^{40}$ investigated the polymorphisms -1087A/G (rs1800896), -824C/T (rs1800871) and -597C/A (rs1800872) in $406 \mathrm{AD}$ patients and 251 unrelated healthy controls from Germany. They found no significant differences in the allelic distribution of these polymorphisms between $\mathrm{AD}$ patients and controls.

Arosio etal. ${ }^{43}$ investigated the prevalence of-1082A/G,-819C/T and $-592 \mathrm{C} / \mathrm{A}$ polymorphisms and $\mathrm{IL}-10$ production by peripheral blood mononuclear cells in $65 \mathrm{AD}$ patients and 65 controls, selected from an Italian population. In the $\mathrm{AD}$ patients, an increase of the $-1082 \mathrm{~A}$ allele and a decrease of $-1082 \mathrm{GG}$ genotype frequencies were observed. They found that the homozygosity for the A allele was associated with a higher risk of $\mathrm{AD}$. The same authors, six years later, analyzed the genotype and allele frequencies of $I L-10-1082 \mathrm{~A} / \mathrm{G}$ polymorphism in 138 patients with MCI diagnosed, respectively, as amnestic (a-MCI) and with multiple impaired cognitive domains (mcd-MCI) in Caucasians from northern Italy ${ }^{44}$. The allele frequencies of this SNP in a-MCI patients were similar to those of $\mathrm{AD}$ patients, whereas those of mcd-MCI patients were comparable to controls. According to the authors, IL-10 may partly explain the conversion of a-MCI to $\mathrm{AD}$, or be a genetic marker of susceptibility ${ }^{43,44}$.

In addition, studying the Italian population, Scassellati et al. analyzed $215 \mathrm{AD}$ patients and 153 controls. They observed that three SNPs $(-1082 \mathrm{~A} / \mathrm{G},-819 \mathrm{C} / \mathrm{T}$ and $-592 \mathrm{C} / \mathrm{A}$ ) were in linkage disequilibrium, resulting in three haplotypes GCC, ACC and ATA. The haplotype GCC/ACC was more frequent in $\mathrm{AD}$ patients ${ }^{4}$. Some years later, another study involving an Italian population investigated allele frequency and distribution of the $-1082 \mathrm{~A} / \mathrm{G}$ and $-819 \mathrm{C} / \mathrm{T}$ polymorphisms in 222 sporadic $\mathrm{AD}$ patients and 179 normal controls. They found that haplotype -1082A/-819T was significantly associated with an increased risk of developing $\mathrm{AD}^{45}$.

Ma et al. ${ }^{46}$ investigated three SNPs $(-1082 \mathrm{~A} / \mathrm{G},-819 \mathrm{C} / \mathrm{T}$ and $-592 \mathrm{C} / \mathrm{A}$ ) in $95 \mathrm{AD}$ patients and 117 age-matched healthy Chinese subjects. They found a strong association between $\mathrm{AD}$ and two $I L-10$ polymorphisms. The reduced expression of $I L-10$ was associated with the $-819 \mathrm{C}$ and $-592 \mathrm{C}$ alleles, and the authors concluded that the functional polymorphisms of the $I L-10$ gene act as a risk factor for $\mathrm{AD}$. 
Table. Association between IL-10 polymorphisms and Alzheimer's disease (AD) in different studies.

\begin{tabular}{|c|c|c|c|c|}
\hline Authors & Location & Groups & $\begin{array}{c}\text { IL-10 } \\
\text { polymorphism(s) }\end{array}$ & Conclusion \\
\hline \multirow{3}{*}{ Depboylu et al., ${ }^{40} 2003$} & \multirow{3}{*}{ Germany } & \multirow{3}{*}{$\begin{array}{c}\text { AD: } 406 \text { Control: } \\
251\end{array}$} & $-1087 A / G$ & \multirow{3}{*}{$\begin{array}{c}\text { No significant differences have been found } \\
\text { between AD patients and controls. }\end{array}$} \\
\hline & & & $-824 \mathrm{C} / \mathrm{T}$ & \\
\hline & & & $-597 \mathrm{C} / \mathrm{A}$ & \\
\hline \multirow{3}{*}{ Lio et al., ${ }^{41} 2003$} & \multirow{3}{*}{ Italy } & \multirow{3}{*}{$\begin{array}{l}\text { AD: } 132 \text { Control: } \\
213\end{array}$} & $-1082 A / G$ & \multirow{3}{*}{$\begin{array}{l}\text { The presence of }-1082 \mathrm{~A} \text { allele associated } \\
\text { with a low production of IL-10, may be } \\
\text { considered as an additive and independent } \\
\text { genetic risk factor for AD. }\end{array}$} \\
\hline & & & $-819 \mathrm{C} / \mathrm{T}$ & \\
\hline & & & $-592 \mathrm{C} / \mathrm{A}$ & \\
\hline \multirow{3}{*}{ Scassellati et al., ${ }^{4} 2004$} & \multirow{3}{*}{ Italy } & \multirow{3}{*}{$\begin{array}{l}\text { AD: } 215 \text { Control: } \\
153\end{array}$} & $-1082 G / A$ & \multirow{3}{*}{$\begin{array}{l}\text { Haplotype frequencies did not reveal } \\
\text { differences. However, the genotype } \\
\text { GCC/ACC was more frequent in AD. }\end{array}$} \\
\hline & & & $-819 \mathrm{C} / \mathrm{T}$ & \\
\hline & & & $-592 C / A$ & \\
\hline \multirow{3}{*}{ Arosio et al., ${ }^{43} 2004$} & \multirow{3}{*}{ Italy } & \multirow{3}{*}{$\begin{array}{l}\text { AD: } 65 \text { Control: } \\
65\end{array}$} & $-1082 A / G$ & \multirow{3}{*}{$\begin{array}{l}\text { In AD there was a significant increase of the } \\
-1082 \mathrm{~A} \text { allele and a decrease of -1082GG } \\
\text { genotype frequencies. }\end{array}$} \\
\hline & & & $-819 \mathrm{C} / \mathrm{T}$ & \\
\hline & & & $-592 \mathrm{C} / \mathrm{A}$ & \\
\hline \multirow{3}{*}{ Ma et al.. ${ }^{46} 2005$} & \multirow{3}{*}{ China } & \multirow{3}{*}{$\begin{array}{l}\text { AD: } 95 \text { Control: } \\
117\end{array}$} & $-1082 A / G$ & \multirow{3}{*}{$\begin{array}{l}\text { The reduced expression of IL-10 } \\
\text { was associated with the }-819 \mathrm{C} \\
\text { and }-592 \mathrm{C} \text { alleles. }\end{array}$} \\
\hline & & & $-819 \mathrm{C} / \mathrm{T}$ & \\
\hline & & & $-592 \mathrm{C} / \mathrm{A}$ & \\
\hline \multirow{3}{*}{ Culpan et al.., 2006} & \multirow{3}{*}{ England } & \multirow{3}{*}{$\begin{array}{l}\text { AD: } 160 \text { Control: } \\
92\end{array}$} & $-3538 \mathrm{~T} / \mathrm{A} /-1354 \mathrm{G} / \mathrm{A}$ & \multirow{3}{*}{$\begin{array}{l}\text { None of the SNPs found to } \\
\text { be associated with AD. }\end{array}$} \\
\hline & & & $-1082 \mathrm{~A} / \mathrm{G} /-819 \mathrm{C} / \mathrm{T}$ & \\
\hline & & & $-592 \mathrm{C} / \mathrm{A}$ & \\
\hline \multirow{2}{*}{ Ramos et al.. ${ }^{48} 2006$} & \multirow{2}{*}{ America } & \multirow{2}{*}{$\begin{array}{l}\text { AD: } 265 \text { Control: } \\
347\end{array}$} & $-1082 A / G$ & \multirow{2}{*}{$\begin{array}{c}\text { No difference was observed between AD } \\
\text { patients and controls. }\end{array}$} \\
\hline & & & $-592 \mathrm{C} / \mathrm{A}$ & \\
\hline Bagnoli et al., ${ }^{45} 2007$ & Italy & AD: 222 Control: & $-1082 A / G$ & Haplotype -1082A/-819T was associated \\
\hline 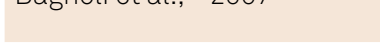 & & 179 & $-819 \mathrm{C} / \mathrm{T}$ & with an increase in the risk of developing AD. \\
\hline Vural et al., ${ }^{49} 2009$ & Turkey & $\begin{array}{c}\text { AD: } 101 \text { Control: } \\
138\end{array}$ & $-1082 A / G$ & $\begin{array}{l}\text { Heterozygous (AG) or A allele carriers } \\
\text { (AG+AA genotype) were associated } \\
\text { with approximately two-fold } \\
\text { increase in the risk of AD. }\end{array}$ \\
\hline Combarros et al.., 25009 & $\begin{array}{l}\text { England, Spain, } \\
\text { Netherland and } \\
\text { Germany }\end{array}$ & $\begin{array}{c}\text { AD: } 1.757 \\
\text { Control: } 6.295\end{array}$ & $-1082 A / G$ & $\begin{array}{l}\text { Dysregulation of the } / L-10 \text { gene contributes } \\
\text { to chronic low-grade inflammation in some } \\
\text { elderly people and increases the risk of AD. }\end{array}$ \\
\hline Arosio et al.. ${ }^{44} 2010$ & Italy & $\begin{array}{l}\mathrm{MCl}: 138 \mathrm{AD} \text { and } \\
\text { Control: Arosio } \\
\text { et al., } 2004\end{array}$ & $-1082 A / G$ & $\begin{array}{l}\text { The allele frequencies of this SNP in } \\
\text { a-MCl subjects were similar to those of } \\
\text { AD patients, whereas those of mcd-MCI } \\
\text { were comparable to controls. }\end{array}$ \\
\hline Ribizzi et al.,50 2010 & Caucasian & AD: 19 Control: & $-1082 A / G$ & The $-819 \mathrm{C}$ allele was raised in $\mathrm{AD}$ group and \\
\hline & population & 20 & $-819 \mathrm{C} / \mathrm{T}$ & associated with low producers of IL-10. \\
\hline Moraes et al., ${ }^{42} 2013$ & Brazil & $\begin{array}{l}\text { AD: } 120 \text { Control: } \\
412\end{array}$ & $-1082 A / G$ & $\begin{array}{l}\text { The SNP - 1082A/G exhibited an effect } \\
\text { in predisposition to the onset of AD. } \\
\text { Almost } 40 \% \text { lower chance of AD among } \\
\text { homozygotes of the IL } 10-1082 A \text { allele. }\end{array}$ \\
\hline Kang et al., ${ }^{53} 2015$ & Korea & $\begin{array}{l}\text { AD: } 86 \text { No AD: } \\
\quad 625\end{array}$ & $-1082 A / G$ & $\begin{array}{l}\text { No significant association between } A D \\
\text { patients and No AD patients. }\end{array}$ \\
\hline & & AD: 122 & $-1082 A / G$ & \\
\hline & & $\begin{array}{c}\text { Vascular } \\
\text { dementia: } 67\end{array}$ & $-819 \mathrm{C} / \mathrm{T}$ & Identified two risk haplotypes (ATA and \\
\hline Vargas-Alarcón et al.,54 2016 & Mexico & $\begin{array}{l}\text { Mixed dementia: } \\
\qquad 32\end{array}$ & & $\begin{array}{l}\text { CIA) and four protection haplotypes } \\
\text { (ATG, CTG, ACG and CCG). }\end{array}$ \\
\hline & & Control: 986 & & \\
\hline & & $\begin{array}{c}\text { Cognitive } \\
\text { impairment: } 135\end{array}$ & $-1082 A / G$ & Haplotype -1082/-819/-592, associated \\
\hline Fraga et al., ${ }^{56} 2016$ & Brazil & Control: 124 & $-819 \mathrm{C} / \mathrm{T}$ & $\begin{array}{c}\text { with lower expression of IL-10 were more } \\
\text { frequent in patient group. }\end{array}$ \\
\hline & & & $-592 \mathrm{C} / \mathrm{A}$ & \\
\hline
\end{tabular}

AD: Alzheimer's disease; MCl: mild cognitive impairment. 


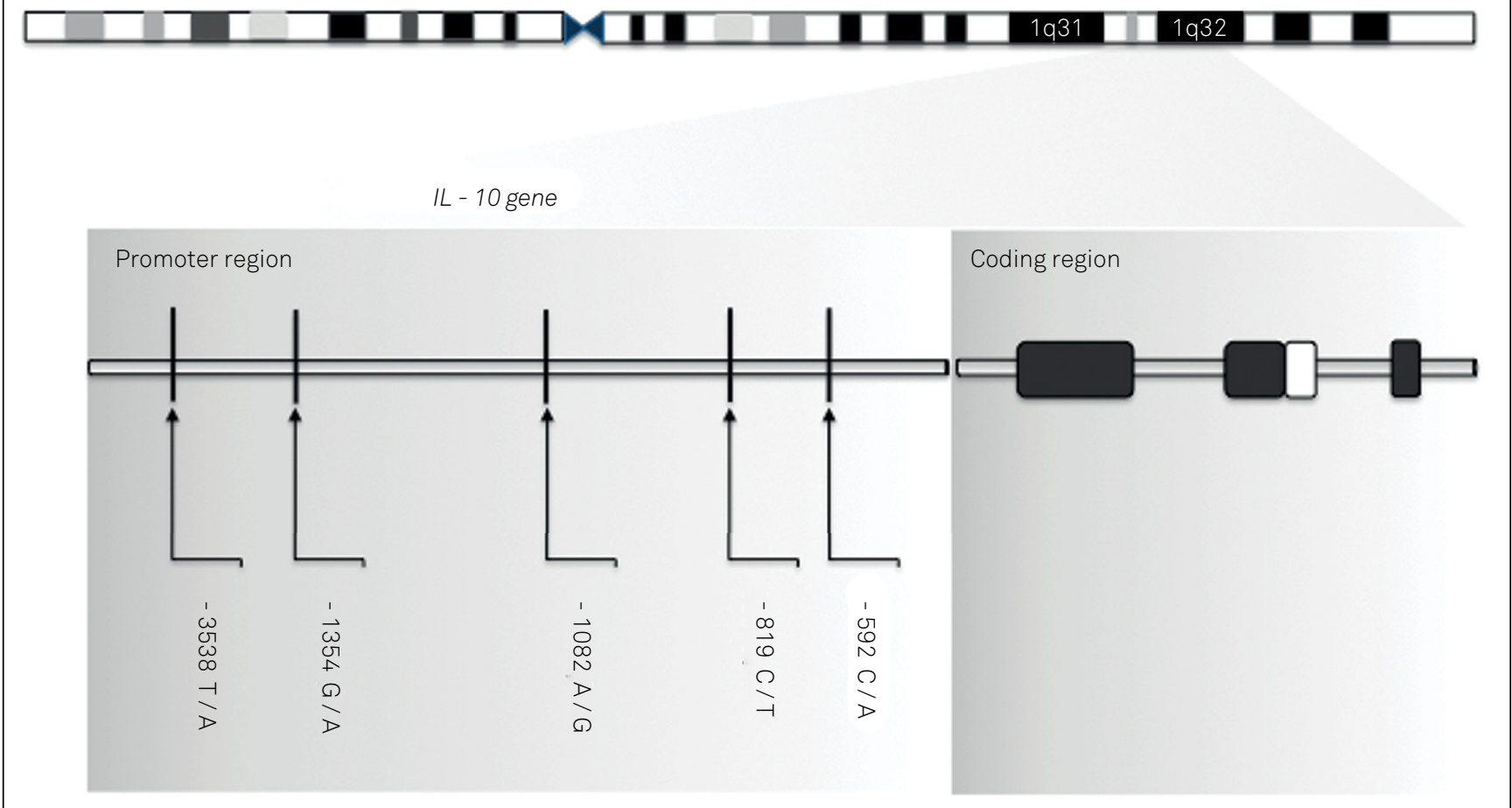

Figure. Chromosome 1, IL-10 gene and SNPs in promotor region.

Culpan et al. ${ }^{47}$, in a retrospective case-control study, examined the brain tissue from 160 patients with neuropathologically confirmed $\mathrm{AD}$ and 92 neuropathologically normal non-demented elderly controls, from a population in England. They evaluated five SNPs -3538T/A (rs1800890), -1354G/A (rs1800893), -1082A/G, -819C/T, -592C/A, and two microsatellites (IL-10-G, IL-10-R) in the promoter region of the $I L-10$ gene. None of the SNPs or microsatellites was found to be associated with AD. Levels of IL-10 protein and gene expression also did not appear to be related to $\mathrm{AD}$. These results are consistent with those reported in Italian and German patients ${ }^{4,40}$, but differed from those in others

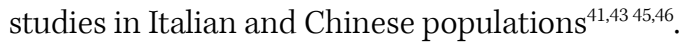

In the same year, Ramos et al. ${ }^{48}$ evaluated the influence of promoter region polymorphisms in the $I L-10$ gene and the risk of late-onset $\mathrm{AD}$ in 265 older white patients and 347 white control subjects in the American population. No difference was observed for $I L-10-1082 \mathrm{~A} / \mathrm{G}$ and -592C/A allelic and genotypic frequencies between the groups.

Vural et al. ${ }^{49}$ investigated the SNP-1082A/G as a susceptibility factor for $\mathrm{AD}$ in 101 sporadic $\mathrm{AD}$ patients and 138 healthy controls in the Turkish population. Heterozygous (AG) or A allele carriers (AG+AA genotype) for this polymorphism were associated with approximately a two-fold increase in the risk of $\mathrm{AD}$.

Ribizzi et al, also analyzing Caucasian individuals, evaluated the genotypic and allelic polymorphisms of 10 cytokine genes $(I L-1 A, I L-1 B, I L-2, I L-4, I L-6, I L-10, I L-12, I F N-G$,
$T G F-\beta, T N F-\alpha$ ), and of cytokine receptors (IL-1R, IL-1RA, IL-4RA) in $19 \mathrm{AD}$ patients and 20 controls affected by non-inflammatory neuropsychiatric disease. They suggested the presence of a proinflammatory environment in $\mathrm{AD}$ patients, corroborated by the low expression of $I L-10$ when the $-819 \mathrm{C}$ allele was present $t^{50}$.

Zhang et al. ${ }^{50}$ performed a meta-analysis on the association between $I L-10-1082 \mathrm{~A} / \mathrm{G}$ polymorphism and $\mathrm{AD}$ risk $(2,158$ patients and 2,088 controls in 12 case-control studies $)^{51}$. The results indicated that $\mathrm{A}$ allele carriers $(\mathrm{AA}+\mathrm{AG})$ had a $27 \%$ increased risk of $\mathrm{AD}$, when compared with the homozygote GG. In the analysis of the ethnic subgroup, significant elevated risk was associated with A allele carriers in Europeans but not in Asians, suggesting genetic diversity among ethnicities. However, because there was only one study performed in Asians, these results may not be valid for this population, according to the authors ${ }^{47}$. Di Bona et al. ${ }^{52}$ also investigated, by meta-analysis, the association of the common $I L-10$ polymorphisms with $\mathrm{AD}$ risk. Fifteen studies investigating the association between the polymorphisms $-1082 \mathrm{~A} / \mathrm{G},-819 \mathrm{C} / \mathrm{T}$ and $-592 \mathrm{C} / \mathrm{A}$ and $\mathrm{AD}$ were analyzed. The data suggested an association between the -1082A allele and risk of $\mathrm{AD}$. They did not find an association with $\mathrm{AD}$ for the $-819 \mathrm{C} / \mathrm{T}$ and $-592 \mathrm{C} / \mathrm{A}$ polymorphisms.

Moraes et $a l .{ }^{42}$ compared the polymorphic genotype distribution across outpatients with late-onset $\mathrm{AD}$ and non-cognitively impaired subjects (120 AD patients and 412 healthy controls) from Brasília, midwest Brazil. They evaluated polymorphisms in $I L-1 \alpha, I L-1 \beta, I L-6, I L-8, I L-10, I L-12 \beta$, 
IL-18, TGF- $\beta 1$, TLR-4 and TNF- $\alpha$ genes. Only IL-10 (-1082A/G) and IL6 (-174C, rs1800795) genes, in recessive and dominant models, respectively, exhibited an effect on the predisposition to $\mathrm{AD}$. Their findings showed an almost $40 \%$ lower chance of $\mathrm{AD}$ among homozygotes of the $I L-10-1082 \mathrm{~A}$ allele $^{42}$.

Kang et al. ${ }^{53}$ investigated the involvement of alleles associated with higher production of proinflammatory and lower production of anti-inflammatory cytokines in 732 elderly Korean individuals with $\mathrm{AD}$ or depression. Genotyping was performed for six pro-inflammatory ( $I L-1 \beta, I L-6, I L-8, T N F-\alpha)$ and two anti- inflammatory ( $I L-4$ and $I L-10-1082 \mathrm{~A} / \mathrm{G})$ cytokines genes. $T N F-\alpha$ and $I L-8$ were significantly associated with $\mathrm{AD}$, and $I L-1 \beta$ with late-life depression. They found no significant association between anti-inflammatory cytokine gene polymorphisms and $\mathrm{AD}$ or late-life depression ${ }^{53}$.

Vargas-Alarcón et al..$^{54}$ conducted the first study in a Mexican population that considered the analysis of $I L-10$ SNPs in patients with $A D$, vascular dementia and mixed dementia (AD/vascular dementia). They analyzed genotypes, allele distributions and haplotypes of $I L-10$ promoter polymorphisms $-592 \mathrm{C} / \mathrm{A},-819 \mathrm{C} / \mathrm{T}$ and $-1082 \mathrm{~A} / \mathrm{G}$, in 986 healthy controls and 221 patients, with 122 patients with $\mathrm{AD}$, 67 with vascular dementia and 32 with mixed dementia. They observed associations between the IL-10 SNPs with mixed dementia when compared with controls, with dominant, and overdominant inheritance models ${ }^{54}$. Moreover, these polymorphisms were associated with a lower risk of developing $\mathrm{AD}$ and vascular dementia when compared with controls. Patients with dementia also showed increased frequency of ATA, CTG, and CTA haplotypes when compared with controls. They identified two risk haplotypes: ATA and CTA and four protection haplotypes: ATG, CTG, ACG and $\mathrm{CCG}^{54}$.

Mun et al..$^{55}$, in a meta-analysis, re-evaluated and updated the associations between IL gene polymorphisms [-889C $>\mathrm{T}$ $(\mathrm{rs} 1800587)$ in $I L-1 \alpha,-511 \mathrm{C}>\mathrm{T}(\mathrm{rs16944})$ in $I L-1 \beta,-174 \mathrm{C}>\mathrm{G}$ (rs1800795) in $I L-6$ and $-1082 \mathrm{G}>\mathrm{A}$ in $I L-10]$ and the risk of $\mathrm{AD}$. Their results suggested that the $-889 \mathrm{C}>\mathrm{T}$ polymorphism may be a potential risk factor in $\mathrm{AD}$. However, the other three polymorphisms, including the $-1082 \mathrm{G}>\mathrm{A}$ polymorphism of $I L-10$, may not be a risk factor for $\mathrm{AD}^{55}$.

Our group investigated the frequency of $I L-10-1082 \mathrm{~A}>\mathrm{G}$, $-819 \mathrm{C}>\mathrm{T}$ and $-592 \mathrm{C}>\mathrm{A}$ SNPs in a sample of healthy and cognitively impaired elderly, to verify the association between these SNPs and the cognitive and functional performance of individuals aged 75 years and above. In this study, 259 Brazilian participants were included, 135 with cognitive impairment (81 with cognitive impairment with no dementia, and 54 demented seniors) and 124 age-matched and gender-matched cognitively healthy controls. The results showed that the haplotypes associated with lower gene expression were more frequent among individuals with cognitive impairment. Moreover, carriers of the $-1082 \mathrm{G}$ allele also had better performances in brief cognitive screening tests. Carriers of $-819 \mathrm{~T}$ and $-592 \mathrm{~A}$ alleles showed worse performance than non-carriers in the same tests. In relation to the $I L-10$ haplotypes, individuals with higher or intermediate expression of IL-10 had better performances in the screening tests. The results suggest a potential role for these SNPs in the development of cognitive impairment with no dementia, and dementia, which may influence the cognitive performance of these patients ${ }^{56}$.

The discrepancies between the studies may be explained by uncontrolled confounding factors, gene-gene interaction or by the fact that some polymorphisms present with different allelic frequencies in certain populations, since genotype distribution of $I L-10$ polymorphisms has been found to be different in Caucasian and Asian populations ${ }^{26}$.

None the studies discussed found differences in either IL-10 haplotype or genotype distributions among $\mathrm{AD}$ patients who did, or did not, carry the allele 4 (epsilon4) of the Apolipoprotein E gene, concluding that the IL-10 polymorphisms are an additive and independent risk factor for $\mathrm{AD}$.

\section{CONCLUSION}

The studies showed that immunity has an important role in $\mathrm{AD}$ onset/progress. Although $I L-10 \mathrm{SNP}$ frequency has shown heterogeneity in different populations, several studies, including our investigation in a Brazilian cohort, suggest that these polymorphisms, particularly -1082A/G, are an important risk factor for $\mathrm{AD}$. However, the mechanism in which IL-10 may ameliorate neuroinflammation, cognitive dysfunction or neurodegeneration is not completely clear. Therefore, other molecular studies, to clarify the $\mathrm{AD}$ etiology, are necessary for solution management and prevention of this complex disease.

\section{References}

1. Alzheimer's Association. 2015 Alzheimer's disease facts and figures. Alzheimers Dement. 2015;11(3):332-84. https://doi.org/10.1016/j.jalz.2015.02.003

2. Heppner FL, Ransohoff RM, Becher B. Immune attack: the role of inflammation in Alzheimer disease. Nat Rev Neurosci. 2015;16(6):358-72. https://doi.org/10.1038/nrn3880

3. Nitrini R, Bottino CM, Albala C, Custodio Capuñay NS, Ketzoian C, Llibre Rodriguez JJ et al. Prevalence of dementia in Latin America: a collaborative study of population-based cohorts. Int Psychogeriatr. 2009;21(4):622-30. https://doi.org/10.1017/S1041610209009430
4. Scassellati C, Zanardini R, Squitti R, Bocchio-Chiavetto L, Bonvicini C, Binetti $\mathrm{G}$ et al. Promoter haplotypes of interleukin-10 gene and sporadic Alzheimer's disease. Neurosci Lett. 2004;356(2):119-22. https://doi.org/10.1016/j.neulet.2003.11.033

5. Swardfager W, Lanctôt K, Rothenburg L, Wong A, Cappell J, Herrmann N. A meta-analysis of cytokines in Alzheimer's disease. Biol Psychiatry. 2010;68(10):930-41. https://doi.org/10.1016/j.biopsych.2010.06.012

6. Rosenberg RN, Lambracht-Washington D, Yu G, Xia W. Genomics of Alzheimer disease: a review. JAMA Neurol. 2016;73(7):867-74. https://doi.org/10.1001/jamaneurol.2016.0301 
7. Blach-Olszewska Z, Zaczynska E, Gustaw-Rothenberg K, Avila-Rodrigues M, Barreto GE, Leszek J et al. The innate immunity in Alzheimer disease- relevance to pathogenesis and therapy. Curr Pharm Des. 2015;21(25):3582-8. https://doi.org/10.2174/1381612821666150710144829

8. Dubois RN. The Jeremiah Metzger Lecture: inflammation, immune modulators, and chronic disease. Trans Am Clin Climatol Assoc. 2015;126:230-6.

9. Sardi F, Fassina L, Venturini L, Inguscio M, Guerriero F, Rolfo E et al. Alzheimer's disease, autoimmunity and inflammation: the good, the bad and the ugly. Autoimmun Rev. 2011;11(2):149-53. https://doi.org/10.1016/j.autrev.2011.09.005

10. Kiyota T, Ingraham KL, Swan RJ, Jacobsen MT, Andrews SJ, Ikezu T. AAV serotype 2/1-mediated gene delivery of anti-inflammatory interleukin-10 enhances neurogenesis and cognitive function in APP+PS1 mice. Gene Ther. 2012;19(7):724-33. https://doi.org/10.1038/gt.2011.126

11. Delaby C, Gabelle A, Blum D, Schraen-Maschke S, Moulinier A, Boulanghien J et al. Central Nervous System and Peripheral Inflammatory Processes in Alzheimer's Disease: Biomarker Profiling Approach. Front Neurol 2015 Aug;6:181. https://doi.org/10.3389/fneur.2015.00181 PMID:26379616

12. Naert G, Rivest S. The role of microglial cell subsets in Alzheimer's disease. Curr Alzheimer Res. 2011;8(2):151-5. https://doi.org/10.2174/156720511795256035

13. Fuster-Matanzo A, Llorens-Martín M, Hernández F, Avila J. Role of neuroinflammation in adult neurogenesis and Alzheimer disease: therapeutic approaches. Mediators Inflamm. 2013;2013:260925. https://doi.org/10.1155/2013/260925

14. Latta $\mathrm{CH}$, Brothers HM, Wilcock DM. Neuroinflammation in Alzheimer's disease: a source of heterogeneity and target for personalized therapy. Neuroscience. 2015;302:103-11. https://doi.org/10.1016/j.neuroscience.2014.09.061

15. Steardo LJr, Bronzuoli MR, lacomino A, Esposito G, Steardo L, Scuderi C. Does neuroinflammation turn on the flame in Alzheimer's disease? Focus on astrocytes. Front Neurosci. 2015;9:259. https://doi.org/10.3389/fnins.2015.00259

16. Singhal G, Jaehne EJ, Corrigan F, Toben C, Baune BT. Inflammasomes in neuroinflammation and changes in brain function: a focused review. Front Neurosci. 2014;8:315. https://doi.org/10.3389/fnins.2014.00315

17. Alam Q, Alam MZ, Mushtaq G, Damanhouri GA, Rasool M, Kamal MA et al. Inflammatory process in Alzheimer's and Parkinson's diseases: central role of cytokines. Curr Pharm Des. 2016;22(5):541-8. https://doi.org/10.2174/1381612822666151125000300

18. Saleem M, Herrmann N, Swardfager W, Eisen R, Lanctôt KL. Inflammatory Markers in Mild Cognitive Impairment: A Meta-Analysis. J Alzheimers Dis. 2015;47(3):669-79. https://doi.org/10.3233/JAD-150042

19. Verkhratsky A, Zorec R, Rodríguez JJ, Parpura V. Astroglia dynamics in ageing and Alzheimer's disease. Curr Opin Pharmacol. 2016;26:74-9. https://doi.org/10.1016/j.coph.2015.09.011

20. Julian A, Dugast E, Ragot S, Krolak-Salmon P, Berrut G, Dantoine T et al. There is no correlation between peripheral inflammation and cognitive status at diagnosis in Alzheimer's disease. Aging Clin Exp Res. 2015;27(5):589-94. https://doi.org/10.1007/s40520-015-0332-5

21. Sabat R. IL-10 family of cytokines. Cytokine Growth Factor Rev. 2010;21(5):315-24. https://doi.org/10.1016/j.cytogfr.2010.11.001

22. Bagyinszky E, Youn YC, An SS, Kim SY. Characterization of inflammatory biomarkers and candidates for diagnosis of Alzheimer's disease. Biochip J. 2014;8(3):155-62. https://doi.org/10.1007/s13206-014-8301-1

23. Fiorentino DF, Bond MW, Mosmann TR. Two types of mouse T helper cell. IV. Th2 clones secrete a factor that inhibits cytokine production by Th1 clones. J Exp Med. 1989;170(6):2081-95. https://doi.org/10.1084/jem.170.6.2081
24. Acuner-Ozbabacan ES, Engin BH, Guven-Maiorov E, Kuzu G, Muratcioglu S, Baspinar A et al. The structural network of Interleukin-10 and its implications in inflammation and cancer. BMC Genomics. 2014;15 Suppl 4:S2. https://doi.org/10.1186/1471-2164-15-S4-S2

25. Combarros O, Duijn CM, Hammond N, Belbin O, Arias-Vásquez A, Cortina-Borja M et al. Replication by the Epistasis Project of the interaction between the genes for IL-6 and IL-10 in the risk of Alzheimer's disease. J Neuroinflammation. 2009;6(1):22. https://doi.org/10.1186/1742-2094-6-22

26. Ma SL, Tang NL, Lam LC, Chiu HF. The association between promoter polymorphism of the interleukin-10 gene and Alzheimer's disease. Neurobiol Aging. 2005;26(7):1005-10. https://doi.org/10.1016/j.neurobiolaging.2004.08.010

27. Rota E, Bellone G, Rocca P, Bergamasco B, Emanuelli G, Ferrero P. Increased intrathecal TGF-beta1, but not IL-12, IFN-gamma and IL-10 levels in Alzheimer's disease patients. Neurol Sci. 2006;27(1):33-9. https://doi.org/10.1007/s10072-006-0562-6

28. Richwine AF, Sparkman NL, Dilger RN, Buchanan JB, Johnson RW. Cognitive deficits in interleukin-10-deficient mice after peripheral injection of lipopolysaccharide. Brain Behav Immun. 2009;23(6):794-802. https://doi.org/10.1016/j.bbi.2009.02.020

29. Henderson VW. Estrogen-containing hormone therapy and Alzheimer's disease risk: understanding discrepant inferences from observational and experimental research. Neuroscience. 2006;138(3):1031-9. https://doi.org/10.1016/j.neuroscience.2005.06.017

30. Ishunina TA, Fischer DF, Swaab DF. Estrogen receptor alpha and its splice variants in the hippocampus in aging and Alzheimer's disease. Neurobiol Aging. 2007;28(11):1670-81. https://doi.org/10.1016/j.neurobiolaging.2006.07.024

31. Luchetti S, Bossers K, Van de Bilt S, Agrapart V, Morales RR, Frajese GV et al. Neurosteroid biosynthetic pathways changes in prefrontal cortex in Alzheimer's disease. Neurobiol Aging. 2011;32(11):1964-76. https://doi.org/10.1016/j.neurobiolaging.2009.12.014

32. Cianciulli A, Dragone T, Calvello R, Porro C, Trotta T, Lofrumento DD et al. IL-10 plays a pivotal role in anti-inflammatory effects of resveratrol in activated microglia cells. Int Immunopharmacol. 2015;24(2):369-76. https://doi.org/10.1016/j.intimp.2014.12.035

33. Guillot-Sestier MV, Doty KR, Gate D, Rodriguez J Jr, Leung BP, Rezai-Zadeh K et al. Il10 deficiency rebalances innate immunity to mitigate Alzheimer-like pathology. Neuron 2015;85(3):534-48. https://doi.org/10.1016/j.neuron.2014.12.068

34. Chakrabarty P, Li A, Ceballos-Diaz C, Eddy JA, Funk CC, Moore B et al. IL-10 alters immunoproteostasis in APP mice, increasing plaque burden and worsening cognitive behavior. Neuron. 2015;85(3):519-33. https://doi.org/10.1016/j.neuron.2014.11.020

35. Bryson KJ, Lynch MA. Linking T cells to Alzheimer's disease: from neurodegeneration to neurorepair. Curr Opin Pharmacol. 2016;26:67-73. https://doi.org/10.1016/j.coph.2015.10.003

36. Zheng C, Zhou XW, Wang JZ. The dual roles of cytokines in Alzheimer's disease: update on interleukins, TNF- $\alpha$, TGF- $\beta$ and IFN- $\gamma$. Transl Neurodegener. 2016;5(1):7. https://doi.org/10.1186/s40035-016-0054-4

37. Fraga VG, Guimarães HC, Lara VP, Teixeira AL, Barbosa MT, Carvalho MG et al. TGF- $\beta 1$ Codon $10 \mathrm{~T}>\mathrm{C}$ polymorphism influences short-term functional and cognitive decline in healthy oldest-old individuals: the Pietà study.J Alzheimers Dis. 2015;48(4):1077-81. https://doi.org/10.3233/JAD-150397

38. Cousin E, Macé S, Rocher C, Dib C, Muzard G, Hannequin D et al. No replication of genetic association between candidate polymorphisms and Alzheimer's disease. Neurobiol Aging. 2011;32(8):1443-51. https://doi.org/10.1016/j.neurobiolaging.2009.09.004

39. Culpan D, Prince JA, Matthews S, Palmer L, Hughes A, Love $S$ et al. Neither sequence variation in the IL-10 gene promoter nor presence of IL-10 protein in the cerebral cortex is associated with Alzheimer's disease. Neurosci Lett. 2006;408(2):141-5. https://doi.org/10.1016/j.neulet.2006.08.068 
40. Depboylu C, Du Y, Müller U, Kurz A, Zimmer R, Riemenschneider M et al. Lack of association of interleukin-10 promoter region polymorphisms with Alzheimer's disease. Neurosci Lett. 2003;342(1-2):132-4. https://doi.org/10.1016/S0304-3940(03)00231-3

41. Lio D, Licastro F, Scola L, Chiappelli M, Grimaldi LM, Crivello A et al. Interleukin-10 promoter polymorphism in sporadic Alzheimer's disease. Genes Immun. 2003;4(3):234-8. https://doi.org/10.1038/sj.gene.6363964

42. Moraes CF, Benedet AL, Souza VC, Lins TC, Camargos EF, Naves JO et al. Cytokine gene polymorphisms and Alzheimer's disease in Brazil. Neuroimmunomodulation. 2013;20(5):239-46. https://doi.org/10.1159/000350368

43. Arosio B, Trabattoni D, Galimberti L, Bucciarelli P, Fasano F, Calabresi $C$ et al. Interleukin-10 and interleukin-6 gene polymorphisms as risk factors for Alzheimer's disease. Neurobiol Aging. 2004;25(8):1009-15. https://doi.org/10.1016/j.neurobiolaging.2003.10.009

44. Arosio B, Mastronardi L, Vergani C, Annoni G. Interleukin-10 promoter polymorphism in mild cognitive impairment and in its clinical evolution. Int J Alzheimers Dis. 2010;20:pii 854527. https://doi.org/10.4061/2010/854527.

45. Bagnoli S, Cellini E, Tedde A, Nacmias B, Piacentini S, Bessi V et al. Association of IL10 promoter polymorphism in Italian Alzheimer's disease. Neurosci Lett. 2007;418(3):262-5. https://doi.org/10.1016/j.neulet.2007.03.030

46. Ma SL, Tang NL, Lam LC, Chiu HF. The association between promoter polymorphism of the interleukin-10 gene and Alzheimer's disease. Neurobiol Aging. 2005;26(7):1005-10. https://doi.org/10.1016/j.neurobiolaging.2004.08.010

47. Culpan D, Prince JA, Matthews S, Palmer L, Hughes A, Love S et al. Neither sequence variation in the $\mathrm{IL}-10$ gene promoter nor presence of $\mathrm{IL}-10$ protein in the cerebral cortex is associated with Alzheimer's disease. Neurosci Lett. 2006;408(2):141-5. https://doi.org/10.1016/j.neulet.2006.08.068

48. Ramos EM, Lin MT, Larson EB, Maezawa I, Tseng LH, Edwards $\mathrm{KL}$ et al. Tumor necrosis factor alpha and interleukin 10 promoter region polymorphisms and risk of late-onset Alzheimer disease. Arch Neurol. 2006;63(8):1165-9. https://doi.org/10.1001/archneur.63.8.1165
49. Vural P, Değirmencioğlu S, Parildar-Karpuzoğlu H,

Doğru-Abbasoğlu S, Hanagasi HA, Karadağ B et al. The combinations of TNFalpha-308 and IL-6-174 or IL-10-1082 genes polymorphisms suggest an association with susceptibility to sporadic late-onset Alzheimer's disease. Acta Neurol Scand. 2009;120(6):396-401. https://doi.org/10.1111/j.1600-0404.2009.01230.x

50. Ribizzi G, Fiordoro S, Barocci S, Ferrari E, Megna M. Cytokine polymorphisms and Alzheimer disease: possible associations. Neurol Sci. 2010;31(3):321-5. https://doi.org/10.1007/s10072-010-0221-9

51. Zhang Y, Zhang J, Tian C, Xiao Y, Li X, He C et al. The -1082G/A polymorphism in IL-10 gene is associated with risk of Alzheimer's disease: a meta-analysis. J Neurol Sci 2011;303(1-2):133-8. https://doi.org/10.1016/j.jns.2010.12.005

52. Di Bona D, Rizzo C, Bonaventura G, Candore G, Caruso C. Association between interleukin-10 polymorphisms and Alzheimer's disease: a systematic review and meta-analysis. J Alzheimers Dis. 2012;29(4):751-9. https://doi.org/10.3233/JAD-2012-111838

53. Kang HJ, Kim JM, Kim SW, Shin IS, Park SW, Kim YH et al. Associations of cytokine genes with Alzheimer's disease and depression in an elderly Korean population. J Neurol Neurosurg Psychiatry. 2015;86(9):1002-7. https://doi.org/10.1136/jnnp-2014-308469

54. Vargas-Alarcón G, Juárez-Cedillo E, Martínez-Rodríguez N, Fragoso JM, García-Hernández N, Juárez-Cedillo T. Association of interleukin-10 polymorphisms with risk factors of Alzheimer's disease and other dementias (SADEM study). Immunol Lett. 2016;177:47-52. https://doi.org/10.1016/j.imlet.2016.07.011

55. Mun MJ, Kim JH, Choi JY, Jang WC. Genetic polymorphisms of interleukin genes and the risk of Alzheimer's disease: an update meta-analysis. Meta Gene. 2016;8:1-10. https://doi.org/10.1016/j.mgene.2016.01.001

56. Fraga VG, Guimarães HC, Teixeira AL, Barbosa MT, Carvalho MG, Caramelli $P$ et al. Polymorphisms in cytokine genes influence cognitive and functional performance in a population aged 75 years and above. Int J Geriatr Psychiatry. 2016;2016. https://doi.org/10.1002/gps.4627 